\title{
DETERMINING SCIENCE TEACHER CANDIDATES' COMPREHENSION LEVEL OF EQUATIONS
}

\author{
Sevgül Çalış (iD, N. Remziye Ergül (iD
}

Department of Science and Mathematics Education, Faculty of Education, Bursa Uludağ University (Turkey) scali@uludag.edu.tr,ergul@uludag.edu.tr

Received January 2019

Accepted May 2019

\section{Abstract}

It is commonly known that mathematics is used in many subjects in physics and chemistry courses and the relations between mathematics and variables are more easily understood. These courses also comprise a number of equations that correspond to a mathematical correlation and are also called formulas. Therefore, the aim of the present study is to determine the level of science teachers to verbally express the meaning of the equations given and comprehension of the mathematical structure of equations.

The data obtained with the help of open-ended questions were analyzed by the content analysis method, one of the qualitative research methods. According to the data obtained, code, category and themes were created.

The study was carried out with science teacher candidates studying at the Faculty of Education of Bursa Uludağ University in the 2017 and 2018 academic year. When the obtained data were evaluated, it was found that majority of the teacher candidates had difficulty in expressing fully the concept of equation, and in perceiving the mathematical structure of the equations and in drawing the graphs of the equations.

Keywords - Equation, Content analysis, Science teacher candidate, Physics education, Chemistry teaching.

\section{To cite this article:}

Çalış, S., \& Ergül, N.R. (2019). Determining science teacher candidates' comprehension level of equations. Journal of Technology and Science Education, 9(3), 467-475. https://doi.org/10.3926/jotse.667

\section{Introduction}

Science courses are the courses where equations are used extensively. Particularly in physics and chemistry courses, we encounter equations under the name of formula. Even though students love to use equations or formulas, since they unfortunately memorize them, it is observed that they have difficulty in comprehending and interpreting the equations they use in problem solving with their scientific content and mathematical meaning. However, the most important condition of being successful in physics and chemistry courses is to know mathematics and be able to use mathematics knowledge (Ergül, 2018; Özdemir, 2006). It is because it is known that mathematics is used in many subjects in the physics and 
chemistry courses, and the relationships between mathematical knowledge and variables are easier to comprehend.

These courses also contain many equations that correspond to a mathematical correlation and are also called formulas. In order for the students to use the equations, they should first understand the content of the equations. An equation is a verbal representation of the relationships between the variables given by symbols. Therefore, the questions such as "what are the variables that make up the equation? How do the relationships between these variables mathematically affect each other?" should be considered primarily. According to Tuminaro (2002), three factors such as knowing the meaning of the symbols in the equation, the variables in the equation and the relationships between variables are important.

There are many studies revealing that students have problems in using mathematical knowledge. For instance, Sherin (2001) drew attention to the problems experienced by the university students in the use of mathematical symbols in solving physics problems.

In his study with science and engineering students Gök (2016) demonstrated that students experienced huge problems in using units and symbols in science. In another study conducted by Leopold and Edgar (2008) with university students, they revealed the problems arising from the lack of using mathematical knowledge in the processing of some basic subjects in chemistry.

Furthermore, as it was stated by Aytekin and Aydin (2017), mathematics subjects were not in line with the science courses, so mathematics was not well integrated into the science courses. Temel, Dündar and Şenol (2015) also stated that this situation was an important problem and it created a gap between mathematics and science courses. However, it is clear that due to the close relations between many concepts in science and mathematics, science teachers have a strong position to use these relationships and in the case of effective use of this relationship, both science teachers and students can benefit from it (Hilton \& Hilton, 2016).

There are also studies that emphasize the lack of mathematical knowledge in the teaching of science courses at elementary school level. Bütüner and Uzun (2011), for instance, stated that teachers experienced problems based on mathematical knowledge and skills, especially during the teaching of subjects in the field of physics, and also expressed that mathematics-based problems in teaching science courses lead to time loss, poor performance, lack of comprehension of the relevant science subjects and low motivation.

Redish and Kuo (2015) stated that students failed to perceive and associate the equations they learned in mathematics courses very differently from the similar equations they learnt in the science courses (especially in physics).

In a study by Deringöl and Gülten (2016), it was concluded that science and mathematics were intertwined and the quantitative data in science could not be accurately expressed without knowing mathematics; besides, the necessity of mathematics skills for success in the science courses was important.

In order to understand a science formula, it is important to know and interpret the mathematical relationship between the variables. According to Ergül (2018) and Bayazit (2011), in the interpretation of the equations, it is important to be able to see the relationship between the variables graphically; it is because recognition of the graphic, drawing and interpretation it is a whole and one of the basic tools of science and mathematics courses.

\subsection{Purpose of the Study}

The purpose of this study is to determine the level of science teacher candidates' ability to verbally express the meaning of the equation given and comprehend the mathematical structure of equations.

Therefore, answers were sought to the following questions. 
1. What are the levels of science teacher candidates' ability to verbally express the meaning of given equations?

2. What are the levels of science teacher candidates' ability to comprehend the mathematical structure of the equations used in the science courses?

3. What are the levels of science teacher candidates' ability to interpret the relationship between the variables in formulas?

\section{Method}

\subsection{Pattern of the Study}

In this study, it was decided to use the content analysis, one of the qualitative research methods. For this reason, document analysis was used to obtain the data and answers were sought for the research questions. According to Çepni (2018), content analysis required in-depth analysis of the collected data and allowed for the explication of previously unclear themes and dimensions.

\subsection{Participants}

The criterion sampling method, one of the purposeful sampling methods was used in the study. According to the criterion sampling method, the participants should be selected among the individuals with certain qualifications (Büyüköztürk, Kiliç-Çakmak, Erkan-Akgün, Karadeniz \& Demirel, 2009). In the selection of prospective teachers, basic physics, basic chemistry and mathematics courses were chosen as the main criteria. The study was carried out in the fall semester of 2017 and 2018 academic year with 47 pre-service science teachers on the volunteer basis who were studying their second year students at the department of Science education at the Faculty of Education in Bursa Uludağ University; however, since the questionnaires that were uncompleted were taken out of the sampling, a total of 44 pre-service teachers were studied with.

\subsection{Data Collection Tool}

Three open-ended questions were developed by the researchers as data collection tools. The questions prepared for internal validity were presented to the opinion of two experts who studies in the field of science education and finalized by making the necessary corrections. In order to measure the suitability of the questions, a preliminary study was conducted on six teacher candidates. Pre-study results were examined by two researchers. For the reliability of the study, the reliability formula proposed by Miles and Huberman (1994) was applied. As a result of the calculation, it was found that the reliability of the study was $90 \%$ and the study was accepted as reliable.

After these steps, the following measurement tool with open-ended questions was distributed to the students.

\section{Scale Questions:}

1. Explain verbally the scientific meaning of the equations given below.

$$
\mathrm{P}=\mathrm{W} / \mathrm{t} \quad \mathrm{F}=\mathrm{GmM} / \mathrm{r}^{2}
$$

2. What kind of equations do the mathematical equations below correspond to?

$$
\mathrm{F}=\mathrm{ma} \quad \mathrm{E}_{\mathrm{k}}=1 / 2 \mathrm{~m} \mathrm{v}^{2}
$$

3. Draw the graphs of the equations given in the second question $\left(\mathrm{F}-\mathrm{a}, \mathrm{E}_{\mathrm{k}}-\mathrm{v}, \mathrm{E}_{\mathrm{k}}-\mathrm{v}^{2}\right)$.

The teacher candidates were given 60 minutes and were asked to answer questions clearly by writing. The candidates were asked to write their best answer for each question. Thus, the total number of code frequencies was intended to produce the number of participants. 


\subsection{Data Analysis}

In the studies aiming to reveal the meaning in the subject to be researched, it was stated by Yildirım and Şimşek (2008) that the content analysis method was appropriate for determining the themes that would conceptualize the data and define the phenomenon. Based on this, content analysis method was used to analyze the data in this study. The purpose of content analysis is to gather semantically similar data under codes and themes and present them to the reader (Çepni, 2018). In the present study, coding was done according to the concepts extracted from the data and categories were formed by considering the similarities and differences of the codes and the themes were formed from the categories. In this process, after the data were evaluated independently by the researchers, they were studied and finalized until the consensus was reached.

From the data obtained as a result of the evaluation, two themes were formed to express the meaning of the given equation verbally and comprehend the mathematical structure of the equations.

\section{Results}

In this part of the study, after examining and analyzing the answers of the candidates to the scale questions, the code, category and themes formed were formed. In the content analysis for the first question, the answers of the candidates for both equations $\left(\mathrm{P}=\mathrm{W} / \mathrm{t}\right.$ and $\left.\mathrm{F}=\mathrm{GmM} / \mathrm{r}^{2}\right)$ were examined individually and 4 categories regarding the theme determined as expressing the meaning of equation verbally correctly were designed in the form of expressing the equation correctly, expressing the equation deficiently and expressing the equation incorrectly and failing to express the equation, and the student responses were collected under 6 codes. The frequency values of the codes given in the tables refer to the number of codes, not the number of students.

\begin{tabular}{|c|c|c|c|c|c|}
\hline Codes & $\mathrm{f}$ & $\%$ & $\begin{array}{c}\text { Equations } \\
\text { in the } 1^{\text {st }} \text { Question }\end{array}$ & Category & Theme \\
\hline Power is the work done in unit of time. & 16 & 36 & \multirow{6}{*}{$\mathrm{P}=\mathrm{W} / \mathrm{t}$} & Correct expression & \multirow{6}{*}{$\begin{array}{l}\text { Expressing the } \\
\text { meaning of the } \\
\text { equation } \\
\text { verbally }\end{array}$} \\
\hline $\begin{array}{l}\text { Power varies depending on work and } \\
\text { time. }\end{array}$ & 7 & 16 & & Deficient & \\
\hline Power is the division of work into & 16 & 36 & & & \\
\hline $\begin{array}{l}\text { Power is the effort that is spent on time } \\
\text { in direct proportion to the work. }\end{array}$ & 2 & 5 & & Incorrect & \\
\hline It is the energy required to begin work. & 1 & 2 & & & \\
\hline No answer & 2 & 5 & & No answer & \\
\hline $\begin{array}{l}\text { The gravitational force is a force that is } \\
\text { proportional to the product of the } \\
\text { masses and is inversely proportional to } \\
\text { the square of the distance. }\end{array}$ & 18 & 41 & \multirow{6}{*}{$\mathrm{F}=\mathrm{GmM} / \mathrm{r}^{2}$} & Correct expression & \multirow{6}{*}{$\begin{array}{l}\text { Expressing the } \\
\text { meaning of the } \\
\text { equation } \\
\text { verbally }\end{array}$} \\
\hline $\begin{array}{l}\text { It shows the gravitational force of two } \\
\text { objects applied to each other }\end{array}$ & 10 & 23 & & & \\
\hline The law of gravitation of masses & 2 & 5 & & $\begin{array}{l}\text { Deficient } \\
\text { expression }\end{array}$ & \\
\hline $\begin{array}{l}\text { It helps us find the gravitational force } \\
\text { between the earth and the sun }\end{array}$ & 1 & 2 & & & \\
\hline $\begin{array}{l}\text { Gravitational force increases linearly } \\
\text { from the world to the earth }\end{array}$ & 3 & 7 & & \begin{tabular}{|l|}
$\begin{array}{l}\text { Incorrect } \\
\text { expression }\end{array}$ \\
\end{tabular} & \\
\hline No answer & 10 & 23 & & No answer & \\
\hline
\end{tabular}

Table 1. Results of the analysis of the first problem in the scale regarding the theme to express the meaning of the equations verbally

As is clear in Table- 1 for the analysis of the first question, the first definition was accepted as correct for the $\mathrm{P}=\mathrm{W} / \mathrm{t}$ equation and while $36 \%$ of the teacher candidates made the correct definition, $52 \%$ of the candidates were unable to make a scientific definition of the concept of power; however, they read the 
magnitudes in the formula and managed to express them. $7 \%$ of the candidates expressed the equation deficiently and $5 \%$ had no answer.

While the number of teacher candidates who made the correct definition for the $\mathrm{F}=\mathrm{GmM} / \mathrm{r}^{2}$ equation in the first question was $41 \%$, the percentage of teacher candidates with deficient expression was $30 \%$. $7 \%$ of the pre-service teachers gave the wrong answer and $23 \%$ of the pre-service teachers were unable to write any answers.

Opinions of some teachers about the scientific definition of the given equations are as follows:

T1: 'Effort created depending on time in direct proportion in the face of the work done.'

T17: Power varies depending on the work and time in the formula. Power cannot be expressed without work and time.'

T21: 'The work done is divided into time.'

T31: 'The energy required to start a work in unit time.'

T37: 'Power depends on work and time. If the work increases, the power increases; if the time decreases, it decreases.'

T2: 'Gravitational force increases linearly from the world to the earth.'

T3: 'It helps us to find the gravitational force between the earth and the sun.'

T28: 'The division of the product of the mass of the two bodies to the square of the distance between them gives the gravitational force between these two bodies.'

In the second question, the answers of the teacher candidates to the question "what kind of equations does the $\mathrm{F}=\mathrm{ma}$ and $\mathrm{E}_{\mathrm{k}}=1 / 2 \mathrm{~m} \mathrm{v}$ equation correspond to mathematically? were analyzed individually and content analysis was performed. After the analysis, 4 categories were determined for the two equations in the form of comprehension the mathematical structure of the equation, correct comprehension, incomplete comprehension, deficient comprehension and no answer.

\begin{tabular}{|c|c|c|c|c|c|}
\hline Codes & f & $\%$ & $\begin{array}{c}\text { Equations } \\
\text { in the } 2^{\text {st }} \text { Question }\end{array}$ & Category & Theme \\
\hline$y=a x+b$ & 2 & 5 & \multirow{6}{*}{$\mathrm{F}=\mathrm{ma}$} & Correct comprehension & \multirow{6}{*}{$\begin{array}{l}\text { Comprehension } \\
\text { of the } \\
\text { mathematical } \\
\text { structure of } \\
\text { equations }\end{array}$} \\
\hline 1st degree equation & 17 & 39 & & Deficient & \\
\hline Linear equation & 6 & 14 & & comprehension & \\
\hline Directly proportional to $\mathrm{F}, \mathrm{m}$ and a & 9 & 20 & & Incorrect & \\
\hline Directly proportional to F, m & 4 & 9 & & comprehension & \\
\hline Do not know & 6 & 14 & & No answer & \\
\hline$y=a x^{2}+b x+c$ & 2 & 5 & \multirow{7}{*}{$\mathrm{E}_{\mathrm{k}}=1 / 2 \mathrm{~m} \mathrm{v}^{2}$} & Correct comprehension & \multirow{7}{*}{$\begin{array}{l}\text { Comprehension } \\
\text { of the } \\
\text { mathematical } \\
\text { structure of } \\
\text { equations }\end{array}$} \\
\hline Parabolic equation & 2 & 5 & & Deficient & \\
\hline $2^{\text {nd }}$ degree equation & 13 & 30 & & comprehension & \\
\hline Directly proportional to E, $\mathrm{m}$ and & 6 & 14 & & & \\
\hline Linear equation & 16 & 36 & & $\begin{array}{l}\text { Incorrect } \\
\text { comprehension }\end{array}$ & \\
\hline Increased momentum & 3 & 7 & & & \\
\hline Do not know & 2 & 5 & & No answer & \\
\hline
\end{tabular}

Table 2. Results of the analysis to the question "What kind of equations do the given equations mathematically correspond to?"

As shown in Table-2 for the analysis of the second question, the first statement for the equation of $\mathrm{F}=\mathrm{ma}$ was accepted as correct and while the teacher candidates who wrote the correct expression were 
$5 \%, 53 \%$ of the teacher candidates failed to write the mathematical equation, but chose to express it verbally. $29 \%$ of the candidates expressed the equation incorrectly and $14 \%$ had no answer.

For the equation of $E_{k}=1 / 2 \mathrm{~m} \mathrm{v}^{2}$, the first expression was accepted as correct and while the teacher candidates who wrote the correct expression were $5 \%, 35 \%$ of the candidates failed to write the mathematical equation, but chose to express it verbally. $57 \%$ of the candidates expressed the equation incorrectly and 5\% had no answer.

What kind of equations do mathematical equations correspond to? The answers of some prospective teachers are as follows:

The answers to the question "What kind of equations do the given equations mathematically correspond to?" given by the teacher candidates are as follows:

T5: If ' $\mathrm{E}=1 / 2 \mathrm{mv}^{2} \mathrm{y}=\mathrm{ax}^{2}+\mathrm{bx}+\mathrm{c}$ is $\mathrm{F}=\mathrm{ma}, \mathrm{y}=\mathrm{ax}+\mathrm{b}$ is linear equation.'

$\mathrm{T} 41:$ ' $\mathrm{E}=1 / 2 \mathrm{~m} \mathrm{v}$ is second degree equation, $\mathrm{F}=\mathrm{ma}$ is first degree equation.'

In the third question, the candidates were asked to draw the graphs of $\left(F-a, E_{k}-v, E_{k}-v^{2}\right)$ belonging to the equation of $\mathrm{F}=\mathrm{ma}$ and $\mathrm{E}_{\mathrm{k}}=1 / 2 \mathrm{~m} \mathrm{v}^{2}$ ). Following the analyses of the answers of the teacher candidates, 3 categories were established in the form of drawing a graph correctly, drawing it incorrectly, failing to draw the graph with a theme determined to comprehend the mathematical structure of the equation for two the equations.

As can be seen from Table 3, it was found that the percentage of the teacher candidates who drew the (F-a) graph for the $\mathrm{F}=$ ma equation correctly was $82 \%$. It was found that the percentage of teacher candidates who drew the graph incorrectly was $16 \%$ and the rate of students who failed to draw was $2 \%$.

\begin{tabular}{|c|c|c|c|c|c|}
\hline Codes & $\mathrm{f}$ & $\%$ & $\begin{array}{c}\text { Equations } \\
\text { in the } 3^{\text {st }} \text { Question }\end{array}$ & Category & Theme \\
\hline Directly proportional to $\mathrm{F}$, a & 36 & 82 & \multirow{5}{*}{ F-a graphic } & Drawing correctly & \multirow{5}{*}{$\begin{array}{l}\text { Level of } \\
\text { establishing the } \\
\text { mathematical } \\
\text { relationship }\end{array}$} \\
\hline Constantly proportional to $\mathrm{F}$, a & 1 & 2 & & & \\
\hline Increasing curve with $\mathrm{F}$, a & 3 & 7 & & Drawing incorrectly & \\
\hline Inversely proportional to $\mathrm{F}$, a & 3 & 7 & & & \\
\hline No answer & 1 & 2 & & No drawing & \\
\hline Increasing curve with $\mathrm{E}_{\mathrm{k}}, \mathrm{v}$ & 9 & 20 & \multirow{5}{*}{$\mathrm{E}_{\mathrm{k}}-\mathrm{v}$ graphic } & Drawing correctly & \multirow{5}{*}{$\begin{array}{l}\text { Level of } \\
\text { establishing the } \\
\text { mathematical } \\
\text { relationship }\end{array}$} \\
\hline Directly proportional to $\mathrm{E}_{\mathrm{k}}, \mathrm{v}$ & 23 & 52 & & & \\
\hline Inversely proportional to $\mathrm{E}_{\mathrm{k}}, \mathrm{v}$ & 2 & 5 & & Drawing incorrectly & \\
\hline Decreasing curve with $\mathrm{E}_{\mathrm{k}}, \mathrm{v}$ & 5 & 11 & & & \\
\hline No answer & 5 & 11 & & No drawing & \\
\hline Directly proportional to $\mathrm{E}_{\mathrm{k}}, \mathrm{v}^{2}$ & 32 & 73 & \multirow{6}{*}{$\mathrm{E}_{\mathrm{k}}-\mathrm{v}^{2}$ graphic } & Drawing correctly & \multirow{6}{*}{$\begin{array}{l}\text { Level of } \\
\text { establishing the } \\
\text { mathematical } \\
\text { relationship }\end{array}$} \\
\hline Increasing curve with $\mathrm{E}_{\mathrm{k}}, \mathrm{v}^{2}$ & 6 & 14 & & & \\
\hline Inversely proportional to $\mathrm{E}_{\mathrm{k}}, \mathrm{v}^{2}$ & 1 & 2 & & & \\
\hline Decreasing curve with $\mathrm{E}_{\mathrm{k}}, \mathrm{v}^{2}$ & 1 & 2 & & wing incorrectly & \\
\hline Parabola & 3 & 7 & & & \\
\hline No answer & 1 & 2 & & No drawing & \\
\hline
\end{tabular}

Table 3. Results for the analysis of the third problem related to drawing the graphics of the equations $\left(\mathrm{F}-\mathrm{a}, \mathrm{E}-\mathrm{v}, \mathrm{E}-\mathrm{v}^{2}\right)$

It was found that the percentage of the teacher candidates who drew the $(\mathrm{E}-\mathrm{v})$ drew the graph for the $E_{k}=1 / 2 \mathrm{~m} \mathrm{v}^{2}$ equation was $20 \%$. It was found that the percentage of teacher candidates who drew the graph incorrectly was $68 \%$ and the rate of students who failed to draw was $11 \%$. 
It was found that the percentage of the teacher candidates who drew the $\left(E-\mathrm{v}^{2}\right)$ drew the graph for the $\mathrm{E}_{\mathrm{k}}=1 / 2 \mathrm{~m} \mathrm{v}^{2}$ equation was $73 \%$. It was found that the percentage of teacher candidates who drew the graph incorrectly was $25 \%$ and the rate of students who failed to draw was $2 \%$.

Examples of some graphics drawn by the teacher candidates are below:

T12:
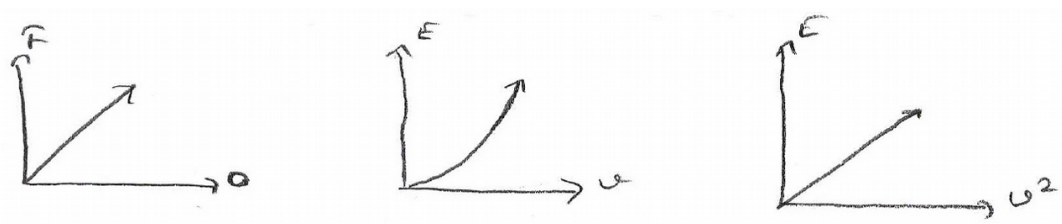

T23:
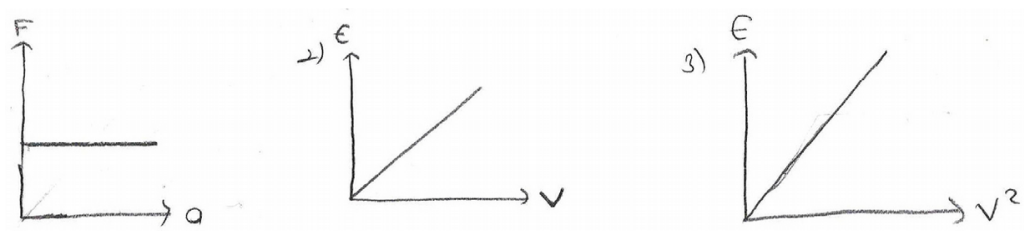

T10:
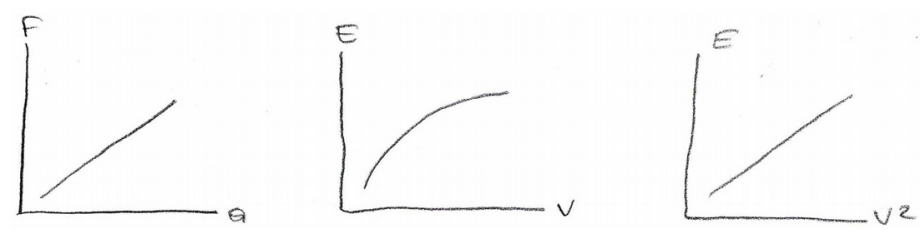

\section{Conclusion}

In the first phase of the study, two well-known equations were given to the teacher candidates who took the General Physics I course at the university and they were asked to write the scientific expression of these equations. As far as the results of the analyses are concerned, it was found that the students had difficulty in verbally expressing the scientific definition of an equation given. More than half of the teacher candidates $(52 \%)$ only recognized the magnitudes in the equation and tried to express these magnitudes in terms of the mathematical relationship between them. This suggests that this is often the result of the habit of finding solutions using the formulas they have memorized in solving problems. This finding can arise from, as a result of the test-solving method commonly used in our education system, the students' trying to find a solution without the need to know the meaning of the given equation.

Secondly, the teacher candidates were given the $\mathrm{F}=\mathrm{ma}$ and $\mathrm{E}_{\mathrm{k}}=1 / 2 \mathrm{~m} \mathrm{v}^{2}$ equations and were asked to write the mathematical equivalent of these equations. When the answers of the candidates were examined, it was found that the number of prospective teachers who could write the exact mathematical formulas for the corresponding equations of $y=a x+b$ and $y=a x^{2}+b x+c$ was extremely low $(5 \%)$. The teacher candidates often found it difficult to write a mathematical formula and expressed them as first or second degree equations instead of writing the formulas. This situation can be interpreted as a result of the gap between mathematics and science courses (Çalıs, 2018; Berlin \& White, 2010). Generally, the previous studies have demonstrated that students and teacher candidates have difficulty in establishing the relationship between physics and mathematics. For instance, in their study with physics teacher candidates, Arslan and Arslan (2010) found that the teacher candidates had difficulties in coming up with a mathematical model representing the physics problem given.

Thirdly, the teacher candidates were asked to draw the $\left(\mathrm{F}-\mathrm{a}, \mathrm{E}-\mathrm{v}, \mathrm{E}-\mathrm{v}^{2}\right)$ graphics for the $\mathrm{F}=\mathrm{ma}$ and $\mathrm{E}_{\mathrm{k}}=1 / 2 \mathrm{~m} \mathrm{v^{2 }}$ equations. Following the analyses of the answers of the teacher candidates, most of the 
teacher candidates $(82 \%)$ correctly draw the graphic by recognizing the linear relationship in the (F-a) graph for the $F=$ ma equation. For the kinetic energy formula, in the drawing of the $\left(E_{k}-v\right.$ and $\left.E_{k}-v^{2}\right)$ graphics, even though most of the teacher candidates drew the $E_{k}-v^{2}$ graph correctly, they failed to draw the $\mathrm{E}_{\mathrm{k}}-\mathrm{v}$ graph. This result indicates that the students could not interpret the equation mathematically, and because they had previously seen similar graphics in the course book or if their teacher had previously drawn the graphic, they could remember that drawing (Ergül, 2018). One of the results of that Leinhard, Zaslavsky and Stein (1990) also found is that students considered the graph as a picture. Therefore, the students chose to display only what was in their minds without questioning the mathematical relationship or thinking about it. In their lab work with undergraduate physics students, Nixon, Godfrey, Mayhew and Wiegert (2016) concluded that the students could be successful in drawing graphics, but generally did not take the underlying physics in the graphics into account.

The integration of science and mathematics education can be suggested as a way of meaningful learning of mathematics and science courses. For instance, since giving examples from physics and chemistry courses in relation to the subjects covered in the mathematics courses, teaching the formulas in physics and chemistry classes by mutually associating them with mathematical equations will make it easier for students to establish interdisciplinary relations by expanding their perspectives on these equations, it is possible to say that they help the students to comprehend the relevant subjects better.

Note: This study was presented as an oral presentation of the 13th National Symposium on Science and Mathematics Education, held in Denizli, Turkey on $04-06$ October 2018.

\section{Declaration of Conflicting Interests}

The authors declared no potential conflicts of interest with respect to the research, authorship, and/or publication of this article.

\section{Funding}

The authors received no financial support for the research, authorship, and/or publication of this article.

\section{References}

Arslan, A.S., \& Arslan, S. (2010). Mathematical models in physics: A study with prospective physics teacher. Scientific Research and Essays, 5(7), 634-640.

Aytekin, C., \& Aydın, F. (2017). Opinions of Science Teachers About Integration of Science and Mathematics Curriculum. Uludağ Üniversitesi Eğitim Fakültesi Dergisi, 30(2), 443-464.

https://doi.org/10.19171/uefad.368850

Bayaz1t, I. (2011). Prospective Teachers' Understanding of Graphs. Gaziantep University Journal of Social Sciences, 10(4), 1325-1346.

Berlin, D.F., \& White, A.L. (2010). Preservice Mathematics and Science Teachers In An Integrated Teacher Preparation Program for Grades 7-12: A 3-Year Study Of Attitudes And Perceptions Related To Integration. International Journal of Science and Mathematics Education, 8(1), 97-115. https://doi.org/10.1007/s10763-009-9164-0

Bütüner, S.Ö., \& Uzun, S. (2011). Fen öğretiminde karşılaşılan matematik temelli sıkıntılar: Fen ve Teknoloji Öğretmenlerinin Tecrübelerinden Yansımalar. Kuramsal Eğitimbilim, 4(2), 262-272.

Büyüköztürk, Ş., Kiliç Çakmak, E., Erkan Akgün, O., Karadeniz, S., \& Demirel, F. (2009). Bilimsel Araştrrma Yöntemleri. Ankara: Pegem Akademi.

Çalış,S. (2018). Fen Bilgisi Öğretmen Adaylarının Denklem Anlayışları ve Kimya Denklemlerini Anlama Düzeyleri. YYÜ Ë̆itim Fakültesi Dergisi (YYU Journal of Education Faculty), 15(1), 903-931.

https://doi.org/10.23891/efdyyu.2018.91 
Çepni, S. (2018). Arasțtrma ve Proje Calısmalarna Giriş. Trabzon: Celepler Matbaacıllik.

Deringöl, Y., \& Gülten D.Ç. (2016). Öğretmen Adaylarının Fen Eğitiminde Matematiğin Kullanılması ile İlgili Görüşleri: Bir Metafor Analizi Çalısması. Ë̆gitim ve Öğretim Araştrmalar Dergisi, 5(1).

Ergül, N.R. (2018). Pre-service Science Teachers' Construction and Interpretation of Graphs. Universal Journal of Educational Research 6(1), 139-144. https://doi.org/10.13189/ujer.2018.060113

Gök, T. (2016). The Importance of Symbols and Units In Natural Science. The Eurasia Proceedings of Educational \& Social Sciences (EPESS), 4, 165-167.

Hilton, A., \& Hilton, G. (2016). Proportional reasoning: An essential component of scientific understanding [online], Teacbing Science, 62(4), 32-42.

Leinhardt, G., Zaslavsky, O., \& Stein, M.K. (1990). Functions, graphs, and graphing: Tasks, learning, and teaching. Review of Educational Research, 60(1), 1-64. https://doi.org/10.3102/00346543060001001

Leopold, D.G., \& Edgar, B. ( 2008). Degree of Mathematics fluency and Success in Second-Semester Introductory Chemistry. Journal of Chemical Education, 85(5). https://doi.org/10.1021/ed085p724

Miles, M.B., \& Huberman, A.M. (1994). Qualitative data analysis: An expanded sourcebook. (2nd ed.). California: SAGE Publications.

Nixon, R.S., Godfrey, T.J., Mayhew, N.T., \& Wiegert, C.C. (2016). Undergraduate student construction and interpretation of graphs in physics lab activities. Physical Review Physics Education Research, 12(1), 010104. https://doi.org/10.1103/PhysRevPhysEducRes.12.010104

Özdemir, N. (2006). İlkëğretim 2. kademedeki fen bilgisi öğretiminde yaşanan sorunlar ve çözüum önerileri. (Yaymlanmamıs yülksek lisans tęi). Pamukkale Üniversitesi Fen Bilimleri Enstitüsü, Denizli.

Redish, E.F., \& Kuo, E. (2015). Language of physics, language of math: disciplinary culture and dynamic epistemology. Sci \& Educ, 24, 561-590. https://doi.org/10.1007/s11191-015-9749-7

Sherin, B.L. (2001). How students understand physics equation. Cognition and instruction, 19(4), 479-541. https://doi.org/10.1207/S1532690XCI1904_3

Temel, H., Dündar, S., \& Şenol, A. (2015). Öğretmenlerin Fen ve Teknoloji Dersinde Matematikten Kaynaklanan Güçlükleri Giderme Yolları ve Fen Matematik Entegrasyonunun Önemi. GEFAD / GUJGEF, 35(1), 153-176.

Tuminaro, J. (2002). How Students Use Mathematics in Physics: A Brief Survey of the Literature, University of Maryland College Park.

Yıldıım, A., \& Şimşek, H. (2008). Sosyal bilimlerde nitel araştırma yöntemleri. Ankara: Seçkin Yayıncılık.

\author{
Published by OmniaScience (www.omniascience.com) \\ Journal of Technology and Science Education, 2019 (www.jotse.org)
}

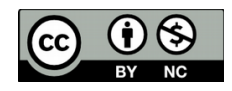

Article's contents are provided on an Attribution-Non Commercial 4.0 Creative commons International License. Readers are allowed to copy, distribute and communicate article's contents, provided the author's and JOTSE journal's names are included. It must not be used for commercial purposes. To see the complete licence contents, please visit https://creativecommons.org/licenses/by-nc/4.0/. 